\title{
Introduction: China's eco-cities and bid to become an eco-civilization
}

The ascendancy of ecology as the main rival to environmentalism in the last decades of the twentieth century was accompanied by an inchoate worldview shaped by several cardinal principles. First, this new philosophical framework emphasized the ecosystem as humankind's true abode and most encompassing system subsuming society and economy. Second, it saw the Enlightenment heritage of modern science and technology either as a savior to mounting environmental devastation, taking the form of ecological modernization-or as an albatross that needed to be supplanted by an alternative modernity more in keeping with ecological values derived from the Otherness of wild feminism, ancient or Eastern religions, or the ecological Indian or other pre-modern or anti-modern traditions. Third, this eco-philosophy called for the pursuit of appropriate technology, the fashioning of humanly-scaled solutions to human communities, the de-colonization of work and leisure, and the replacement of limitless human desires expressed in consumer wants with the riches of human needs expressed in sociality, conviviality, meaningful work, and beloved communities.

If these characteristics of a new ecological worldview shaped the emergent cultural and political landscape of Europe and North America and more ambiguously informed the concept of sustainability or sustainable development heralded by the Brundtland Commission report published in 1987, the growth of sustainable cities would seem to be the most visible sign and overt expression of a new local-global impulse seeking to reverse modern societies' seemingly relentless and quickening overshoot and collapse and the global ecosystem's descent into wrack and ruin.

Running counter to these hopeful signs, the specter of worsening global warming stemming from concerted action by a mobilized community of nations and worsening trends in the international realm - including the rise and spread of right-wing populism, heightened capitalist globalization, and countervailing policies of economic nationalism and protectionism in the United States and Britain — seemed to undercut progress toward a sustainable world. In the face of these alarming tendencies, China's eco-city initiatives, quietly born in the mid-1980s and little noticed in the West, have moved apace across much of the country well into the second decade of the new millennium. 
This book focuses on the emergence and diffusion of "eco-city" and "low-carbon eco-city" initiatives across the People's Republic of China. Our first book on urban sustainability, The City as Fulcrum of Global Sustainability (2011), sought to outline the origins, design philosophy, and case studies of representative sustainable cities in North America, Europe, and China initiated by us over thirty years of involvement in the theory, design, and practice of the University of Kentucky Center for Sustainable Cities, of which the current authors are co-directors. The second book, Getting from Here to There? Power, Politics, and Urban Sustainability in North America (2016), endeavored to explore more deeply the politics of urban sustainability in eight towns and cities in the United States and Canada, examining the comparative dimensions of these urban sustainability enterprises through a grasp of similarities and differences between these two nations gained from prior studies and field trips.

With this third book, From Eco-Cities to Sustainable City-Regions: China's Uncertain Quest for an Ecological Civilization, we explore the many and sometimes contradictory paths China has pursued, and is currently pursuing, to advance urban sustainability, mitigate the threat of greenhouse gases upon the globe's climate, and generate energy sufficient to power twenty-first century science and technological progress and a modern high-tech society. Answers to the questions about where China is going in its pursuit of eco-urbanization, what road it might ultimately take, and whether its sustainability pathways will even converge are not at all clear and obvious at this time.

We thus seek in this work to expand and consolidate our collaborative studies of Chinese politics and its eco-city developments into an analysis that investigates the successes and failures, the strengths and weaknesses, of China's expansive, ambitious, and, in some ways, contradictory local-national programs. In so doing, we strive to advance ecological, climate change, and economic solutions to continuing environmental pollution and ecological degradation, mounting greenhouse gas levels, and unbroken (especially) economic development in its expanding number of growing eco-cities and diminishing countryside.

\section{CHINA'S CONTRADICTORY PURSUIT OF GLOBAL LEADERSHIP TOWARD A LOW-CARBON, URBAN-ECOLOGICAL FUTURE}

If the twentieth century was variously labeled the American Century or the Century of Total War, the twenty-first century may likely be designated the Century of China or the Century of Climate Change — or both. Signs and tokens of this strong candidate (or candidates) are evident in the emergence of a new sort of urbanization across the Chinese landscape taking the form of eco-cities 
and its low-carbon city, low-carbon eco-city, smart-city, knowledge-city variants. Further indicators are evidenced in this East Asian powerhouse in its rapid ascendancy to a leadership position in renewable energy production in wind power, hydropower, and solar energy. Accompanying this "Green Leap Forward" has been the adoption of sustainability-oriented techniques and policies such as its development of a circular economy and its larger quest to achieve national goals framed in terms of becoming an "ecological civilization." Even its continued exploitation of its coal reserves, which has been a major culprit in contributing to its environmental devastation and global greenhouse gas concentrations, has been counterbalanced by its collaborative search for clean coal technology with the United States. If these ambitious and vigorously pursued developments have sometimes been marred by their mega-scaled character, the breadth of these programs and initiatives leave little doubt that China has committed many of its abundant financial, technological, and human resources to the project of going green in a big, ostentatious, and determined way.

Profoundly informing - and simultaneously vitiating - these pluralistic efforts to follow a sustainability path is China's shift, beginning in 1979, to "Socialism with Chinese Characteristics" through the stewardship and direction of Deng Xiaoping. In striving to overcome the voluntarist and mass mobilization techniques of the Cultural Revolution triggered by Mao Zedong to rekindle the revolutionary fervor and ideological goals of the original Chinese Communist victory, Deng sought to set China on a new course intended to renovate the early economic institutions, work and social welfare programs, and urban and rural policies that would soon heighten wealth and income inequality, worsen environmental pollution and degradation, shred its social safety net, and increasingly integrate China into the global economy. With these sharp departures from Maoist Communist ideology came the primacy of developmentalism and neo-liberalism, the pursuit of national modernity and modernization, and the reformulation of the authoritarian party-state's hegemonic strategy depending increasingly upon the use of its media monopoly and other means of ideological persuasion for mobilizing popular consent, though always backed when necessary by the coercive power of its agencies of force and violence. So, even as China embarked upon a wide-ranging campaign to clean up its air, water, and land and build an ecological civilization, its fealty to maintaining heightened levels of economic growth and scientific-technological development remained at the heart of its evolving eco-city strategy. 


\section{BASIC ARCHITECTURE AND KEY THRUST OF THE BOOK}

The literature on Chinese eco-cities, low-carbon cities, and eco-knowledge cities by Western and Asian scholars, mostly in English and somewhat less so in Mandarin Chinese, is growing and very helpful in getting oriented to the phenomena. These works have been abundantly supplemented by the growing number of sustainable city/eco-city researchers in China, Europe, and the United States and Canada who have performed fieldwork motivated by a range of issues and questions often driven by disciplinary (geography, anthropology, political science, sociology, management studies) or interdisciplinary (Asian and Chinese studies, comparative literature) imperatives.

Among the many committed scholars and researchers pursuing these studies, we have greatly benefited from the work of those specialists affiliated with or organized around Delft University and the University of Westminster-researchers who have often collaborated with native Chinese scholars to their enormous benefit. Among the Delft University group, Martin de Jong and his collaborators have been valuable guides in developing issues and new directions in the study of Chinese eco-cities. Recently, de Jong and his co-authors (2016) have identified a useful typology for clustering the many (over 285) Chinese urban initiatives in sustainable urbanization:

- type \#1: eco-cities with strong national government support, paired with structured foreign involvement;

- type \#2: city initiatives with limited national government support, paired with occasional foreign involvement;

- type \#3: city programs with nominal support from national government;

- type \#4: local initiatives without national government support.

Naturally, there are other ways to order China's manifold eco-urban initiatives. For example, one could separate them into eco-city and low-carbon city types. Or one could divide them according to scale (town, district, city, county, or province). Yet another way might to be rank them according to cities with different population levels (small, medium, or large). Still more, such eco-initiatives could be separated into unfinished or unrealized, completed and therefore (in some sense) successful, or stalled or even morbid ones.

Having chosen to organize fieldwork according to de Jong et al.'s schema, we decided to investigate the following urban-ecological programs through the accumulation of master plans and other documents, fieldwork at individ- 
ual sites, urban planning bureaus and institutes, municipal urban planning museums, and interviews aided by native translators:

- Type \#1: the Sino-Singapore Tianjin Eco-city;

- Type \#2: the International (formerly Sino-Swedish) Wuxi Taihu New Town or Eco-city;

- Type \#3: the SND and Suzhou Eco-Town;

- Type \#4: the Kunming-Chenggong Low-carbon Eco-city;

- Type \#5 (new or emergent): Shantou Coastal, Metropolitan Garden City.

The Sino-Singapore Tianjin Eco-city project fits into the type \#1 category and is arguably the most noteworthy eco-city program in China, having replaced the now defunct Dongtan-Chongming Island project as the country's showcase-to-the-world sustainability initiative. The former Sino-Swedish, now Wuxi Taihu New Town or Eco-city initiative fits nicely into the type \#2 category; and, despite limited central government support, it seems to be making reasonable progress. The Suzhou Eco-town initiative is a modest venture that has already attracted international consultant interest and involvement and is likely to build upon the foundation of its completed eco-industrial park and find investors to support its implementation and completion. Our type \#4 example, the Kunming-Chenggong low-carbon eco-city program is one of the only such projects in western China and has had a significant impact upon Kunming and its political and educational institutions.

These four sites are representative of the four-category typology formulated by de Jong and his associates and highlight both common and variegated features of the eco-city program in China. These categories or types allow us to analyze, assess, and critique this significant venture and its global implications for promoting urban sustainability, climate change mitigation, and sustainable economic development. These case studies constitute four chapters of this book. Intended less to work from a common outline or framework for comparison, these urban initiatives seek to underscore distinctive elements of each one and draw upon the diverse literature on Chinese eco-cities to date opened up by the fieldwork and that contributes to the different methodological, theoretical, and empirical patterns uncovered in these earlier studies. Nonetheless, it is hoped that their representativeness will allow for some degree of generalization to the larger universe of eco-urbanization projects in China.

A fifth site-Shantou - was selected by a combination of happenstance and design. That is, one of us (Yanarella) had the good fortune to teach a course on the City of Shantou as a living laboratory for sustainable urban design twice at Shantou University's summer program (2014 and 2015). Fortuitously, this was a time when public officials and urban planners were rolling out a sustainable 
development plan and master plan that raised critical questions and issues for the University's senior seminars about the city and its region.

Choosing Shantou then allows us to identify and construct a fifth category or type: cities not yet identified as eco-cities but with emergent eco-city policy aspirations. Shantou recently (2013) underwent a process of sponsoring an international design competition among noted global consultancies supervised by a prominent Chinese urban design and planning institute to select winning designs that were then (2015) incorporated into the framework of its new master plan. This process is likely to lead to a city campaign to solicit central government interest and eco-city designation by one of the central government's key planning agencies and to attract financial support and investment by former native Shantouan entrepreneurs who have become wealthy from enterprises they built across East Asia.

\section{OBJECTIVES}

The purpose of studying these initiatives is five-fold. First, we are interested in looking at the origins, genealogy, and potential of the Chinese eco-cities phenomenon by tapping into the way that China's cultural-spiritual traditions - Confucianism and Daoism - have been absorbed and mediated through Chinese Communism and its Deng Xiaoping offshoot, socialism with Chinese characteristics. We also want to explore the Soviet origins of China's eco-city development. Second, we believe these five urban sustainable projects exemplify many of the characteristics of other city experiments across China fitting into each of the four (and perhaps five) types developed by de Jong et al. and added by us. It is likely that they also illustrate many of the same internal and external drivers propelling the Chinese sustainable urbanization process since the late 1990s and early 2000s. Third, because the third leg of the sustainability tripod or stool-social equity-is so often neglected in sustainability projects, we wish to explore the treatment of rural villagers whose land has been expropriated for these sites and the fairness and impact of any compensation packages traded by the local, district, or state administrations for those land holdings. Fourth, China's three major supervisory ministries and agencies - the Ministry of Housing and Urban-Rural Development (MoHURD), the Ministry of Environmental Protection (MEP), and the National Development and Reform Commission (NDRC)-have established criteria for selection of Chinese cities as eco-cities, districts, and counties (MEP), low-carbon eco-cities (MoHURD), and low-carbon provinces and cities (NDRC), as well as eco-city indicators being utilized to assess progress toward achieving ecological/sustainability/low-carbon objectives. We examine these reports to determine both the degree of success and relevance of these evaluative indicators/performance standards to these programs as they 
seek to realize their goals and ambitions. Fifth, we assess these projects using the urban sustainability metric and criteria that have been developed from the parallel and often convergent work of Rees and Wackernagel (ecological footprint, fair Earthshare, and policy component strategy) and Levine and Yanarella (Sustainable Area Budget, Sustainable City Game, Sustainability Engine $^{\mathrm{TM}}$, and Sustainable Urban Implantation). By applying these tools and employing this independent perspective derived from a strong sustainability model, we attempt to offer a rounded policy evaluation of the present course of China's sustainable urbanization program and uncover a host of policy recommendations germane to the Chinese political/ecological context. Our hope is that these policy proposals will provide valuable lessons for such urban sustainability programs in China and elsewhere in the developing and developed worlds. In sum, the research outcomes are driven by a research project to develop theoretical case studies in a comparative framework that will yield germane policy advice.

\section{CHINESE IDEOLOGICAL-CULTURAL RESOURCES FOR LEADING THE WAY TO GLOBAL SUSTAINABILITY}

Because we are adopting a critical approach to Chinese eco-urbanization development and its patterned, but pluralistic, eco-city strategy, it is important that we strive to avoid succumbing to what Edward Said has called Orientalism and Daniel Vukovich has termed Sino-Orientalism. As we will relate in succeeding chapters, this orientation is one that academicians and policy makers often adopt-wittingly or unwittingly - toward parts of the geographical areas identified with the Orient_-in Said's case, especially societies of the Middle East and North Africa, and in Vukovich's case, East Asia, particularly China. This orientation or attitude among Western scholars and governmental policy toward these societies or cultures leads them to take a position of intellectual-scientific, socio-economic, and cultural superiority vis-à-vis these countries that while attributing to them backwardness and inferiority also sees them as slowly, but inexorably becoming more like the West in their social and cultural domains.

At the same time, because parts of this work will be governed by a belief in the value of an alternative strategy of eco-cities - that we call the strategy of sustainable city-regions - in what will amount to a critique of the major thrust of Chinese eco-scientific development principles and practices, we wish to acknowledge two key points at the outset. First, the academic debate over Chinese methods of promoting ecological civilization in general and eco-city development found in the literature is unlikely to affect the substance and direction of such policy directives and developments by those party 
figures and administrators supervising MoHURD, MEP, and NDRC. On the other hand, as we will exhibit, Chinese eco-cities have often drawn upon the guidance and lessons offered by international consultants and foreign sustainability models and techniques. So, it is possible that knowledge produced in the West like ours and future eco-city initiatives in China guided in part by alternative eco-frameworks may have some influence on the evolution of this high-priority Chinese program. The growing collaboration of Chinese and foreign researchers on such studies and the national government's sponsorship of conferences and workshops featuring international and native scholars are hopeful bellwethers of this possibility.

Second, there are longstanding and emerging elements of China's history, culture, and religions that provide it with certain advantages over other nations and regions of the world in charting a sustainable future. It can lead the rest of the world to that future beyond a scenario characterized by global overshoot and collapse (the capitalist-modernization-run-amok scenario) and/or a world ruined by runaway greenhouse gases (i.e. the Earth-as-Venus scenario). The environmental histories of China written by Marks (2017) and Elvin (2004) demonstrate the natural resource deficits, economically rapacious practices, ideologically foolhardy policies, and other contingent factors that have contributed to its present-day calamitous environmental circumstances (triggering, for example, extensive water and inland atmospheric pollution, "cancer villages," and other public health problems) and a meager and eroded natural resource base (e.g. diminished arable land, forested areas, and regional water scarcity). Still, two other recent works on China's (and other Asian) religious and cultural traditions point to decidedly indigenous resources that may yet be mobilized to assist China in leading the way to local-global sustainability.

\section{Duara's The Crisis of Global Modernity: Asian Traditions and a Sustainable Future}

Prasenjit Duara's most recent book (2015) offers an unsparing analysis and critique of a Western modernity that is rapidly making over the world into a gigantic factory of production and consumption and degrading the Earth by sapping it of its fecundity and capacity to promote human flourishing-all in the name of economic growth and modernization. At the same time, its attentiveness to Chinese, Indian, and global histories, values, and ideas that have intersected, circulated, and looped back amongst themselves goes far in framing a basis in Asian history, society, and culture that limns signposts for not only an alternative modernity, but a way of nurturing a global commons that pulls humankind back from the catastrophic consequences of the present hegemony of the Western project of modernity. Rebuffing the linear histories that camouflage more than they reveal, Duara offers a rich and illuminating 
analysis of how Asian religions and philosophies may provide reasoned hope for a sustainable future that is at once local and emplaced and global and circulating at many different scales. While acknowledging the promise of the Enlightenment modernity captured in its representation of equality, justice, and freedom, Duara underscores the other pole of the dialectic of Enlightenment (and domination) - i.e. the license of Western science and technology to unleash the power of "the freedom to treat nature and the world as objects and resources for man-leading to unsustainability” (Duara 2015: 118).

His careful and patient clarification of circulating histories, dialogical transcendence, historical logics of global modernity and trafficking between secularism and transcendence, networks of sustainability, and hope and the commons offers new concepts and perspectives that reward the serious reader in an abundance of ways. His defense of Asian traditions - particularly those of China and India - against the shortcomings and collusion of Abrahamic religions with Western modernity's underside (noted above) will prove a challenge to the believers of Christianity, Judaism, and Muslim religions regarding their contribution to the crisis of global modernity. No less significant is his indictment of "the untrammeled power of capitalist consumption and the imperative felt by national populaces and their leaders to avoid sacrificing national interest at all_or perhaps, almost all, costs" (Duara 2015: 29). The rise of the nation-state and the tenacious hold of national political elites on that system have thus posed enormous obstacles in the path of building sustainable towns and cities and networking them across the North-South divide.

Along the way, Duara shows his respect for aspects of twentieth-century philosophy and its relevance and circulation of ideas and concepts of Western thinkers such as Karl Jaspers, Jürgen Habermas, Ernst Bloch, Michel Foucault, and Jacques Derrida. From Jaspers and Habermas, he takes up the importance of the Axial Age theory to clarify and open up the notion of transcendence to innovation and reframing in a manner that acknowledges its importance to global sustainability without continuing to carry the baggage of the kind of radical transcendence of the Abrahamic religions of an absolute and all-powerful God. Instead, he embraces Simmel's understanding of religion as "the objectification of human yearning," seeing it as "an aspect of human subjectivity" (Duara 2015: 5). His goal is to overcome a notion of radical transcendence built upon a categorical opposition between transcendence and immanence so that in our increasingly secular age a new, dialogical transcendence can both resonate with emergent aspirations and realities and establish a certain distance from worldly transcendental authority so as to maintain "its capacity for regeneration, not the capacity to totalize from the conviction of absolute truth" (Duara 2015: 108), such as we have seen in the many fundamentalisms wracking the world today. 
In his closing reprise and epilogue, titled, "Of Reason and Hope," he ponders whether the "task of mediating the sacred with reason could be eased if we recognize that the gap between ideal, project, and effort and its realization may be occupied not principally by faith or belief, but by hope" (Duara 2015: 284). This epiphany thrusts him into the arms of Ernst Bloch, the great philosopher of hope, whose secularization of hope in his book The Atheism in Religion: The Religion of the Exodus and the Kingdom, means that "secularism is necessary for humans to walk on their own feet; but, at the same time, to realize that religions also embed their utopian hope so necessary for humans" (Duara 2015: 285, fn. 8). With sustainability under severe challenge and hope in short supply, Duara speaks to the many millions rallying around the banner of sustainability and offers a succinct summary of his book's message:

Hope as an essential ingredient of a transcendent force may allow for more dialogi$\mathrm{cal}$ and honest engagement with messy realities. Achievements, to be sure, are liable to be politically appropriated for some other sacred purpose such as the nation, but this may be a fight worth fighting. Indeed, the decentered, multiply ordered networks are already beginning to create new objects, spaces and flows of sacrality and inviolability founded on their hopes of a sustainable world. These spaces furnish them with the autonomy required to launch resistance and regeneration. (Duara 2015: 287)

The import of Duara's rich and sophisticated exercise in comparative history and historical sociology for our book and its focus on China's deficits and resources for building eco-cities grounded in strong sustainability is plural. First, it points to a way forward, back, and around to ideas, principles, and resources often borne in Chinese and Indian traditions to attain the goals animating the struggle for sustainability. That is, his book illuminates how the comparative freedom of China's cultural and religious traditions from the absolutism ignited by the radical transcendentalism of the three Abrahamic religions offers a better foundation more in keeping with pressing twenty-first century needs for fashioning a sustainable modernity. Second, in his analysis of the regionally and globally scaled politics of NGOs and other international and regional players, he finds transnational actors who may yet break the grip of transnational corporations shaping the top-down processes of capitalist globalization abetted by the bottom-up nation-states whose politics, policies, and programs block more than foster patterns of sustainable modernity that are haltingly circulating through ideas, processes, and policies so desperately required for the world to step back from the brink of apocalyptic trends and possibilities. 


\section{Daoism and Ecology: James Miller's China's Green Religion: Daoism and the Quest for a Sustainable Future}

Several recently published books by religious studies researchers and like-minded students of East Asian cultural and philosophical traditions (Girardot, Miller, and Liu 2001; Miller, Yu, and van der Veer 2014; Stikker 2014; Tucker and Bethrong 1998) have also weighed this possibility of a productive and interpenetration of Daoist, Buddhist, and Confucian ideas and values and ecological goals and aspirations that might counter the authoritarian and Enlightenment impulses informing the Chinese party-state's current grip on national programs and policies related to economic development and eco-modernization strategy (see Table I.1).

Among these writers, James Miller has emerged as a leading scholar of Eastern religions and perhaps one of the strongest voices for the relevance of these religions - particularly Daoism - for affecting a Chinese grassroots campaign to recuperate these ancient resources and then re-function them in the present and near future to advance an ecological agenda in China and elsewhere. In important respects, Miller's recent follow-up to his previous books on Daoist and other Eastern religions both complements and reinforces the arguments in Duara's book to find in Chinese religious resources the means for building a sustainable future. As he has succinctly put it:

The monumental task that China faces in the 21 st century is to create a way of development that does not destroy the ecological foundations for the life and livelihood of its 1.4 billion citizens. This requires a creative leap beyond the Enlightenment mentality and the Western model of industrialization. Can China's cultural traditions, its religious values, ideals and ways of life, play a role in building a sustainable China? What can these native cultural traditions and religions contribute to this monumental task? (Miller 2014)

From a Western perspective, this ambitious research program and formidable political and cultural task might seem to be mere folly, given the powerful trends toward further centralization of power and prerogative by the Xi Jinping regime and its tight control over recognized religions and its condemnation and periodic repression of those folk and popular religions labeled superstitions. Yet even in this atmosphere of close monitoring and occasional suppression of religious streams by an officially atheistic regime which regards religion as based on mere illusion, Chinese religions continue to vie for the allegiance of the Chinese people's souls (Johnson 2017).

James Miller's book, China's Green Religion: Daoism and the Quest for a Sustainable Future (2017) is nothing less than a masterful reconstruction of Daoist philosophy and religion that offers a twenty-first century guide for overcoming the alienated binaries (humans/nature, self/other, earth/cosmos, 


\section{Table I.1 Daoism, Buddhism, and Confucianism compared}

\begin{tabular}{|c|c|c|c|}
\hline Categories & Daoism & Buddhism & Confucianism \\
\hline Founder: & Lao Tzu & Buddha (Siddhartha) & Kong Qiu/Confucius \\
\hline Holy texts: & Daodejing, Zhuangzi & $\begin{array}{l}\text { Tripitaka, a vast } \\
\text { canon composed of: } \\
\text { the Discourses, the } \\
\text { Discipline, and the } \\
\text { Commentaries; includes } \\
\text { earlier texts, such as the } \\
\text { Gandhara writings }\end{array}$ & $\begin{array}{l}\text { Analects of Confucius } \\
\text { and Mencius, I Ching, } \\
\text { Doctrine of the Mean, } \\
\text { etc. }\end{array}$ \\
\hline Deity or deities: & $\begin{array}{l}\text { No personal God; Dao } \\
\text { is often translated as the } \\
\text { Way, the movement of } \\
\text { a dynamic balancing } \\
\text { composed of two } \\
\text { interacting forces } \\
\text { operating in this world }\end{array}$ & $\begin{array}{l}\text { The notion of an } \\
\text { all-knowing and } \\
\text { all-powerful creator and } \\
\text { transcendental godhead } \\
\text { is foreign to Buddhism } \\
\text { and rejected by its } \\
\text { followers }\end{array}$ & $\begin{array}{l}\text { Belief in the Tian who } \\
\text { is not a transcendent } \\
\text { God as in the Abrahamic } \\
\text { religious traditions, } \\
\text { but a force that set } \\
\text { Confucius on the path } \\
\text { to become a wise man; } \\
\text { ancestors worshipped }\end{array}$ \\
\hline Issue of afterlife: & $\begin{array}{l}\text { Immortality rarely } \\
\text { achieved and only by } \\
\text { exemplary ones in life; } \\
\text { the Tao continues to } \\
\text { evolve and manifest } \\
\text { itself in different forms, } \\
\text { including in all sentient } \\
\text { and non-sentient beings, } \\
\text { in accordance with } \\
\text { the entity's general } \\
\text { conduct during a state of } \\
\text { existence }\end{array}$ & $\begin{array}{l}\text { Rebirth is one of this } \\
\text { religion's central beliefs, } \\
\text { claiming that humans } \\
\text { are in an endless cycle } \\
\text { of birth, death, and } \\
\text { rebirth, which can only } \\
\text { be broken by attaining } \\
\text { nirvana, which allows } \\
\text { one to permanently } \\
\text { overcome suffering }\end{array}$ & $\begin{array}{l}\text { To be worshipped as } \\
\text { ancestors }\end{array}$ \\
\hline Practices: & $\begin{array}{l}\text { Philosophical maturity, } \\
\text { virtuous conduct, } \\
\text { internal alchemy, } \\
\text { harmony in accord with } \\
\text { the natural, and certain } \\
\text { sexual practices }\end{array}$ & $\begin{array}{l}\text { Meditation, the Eightfold } \\
\text { Path; proper view; right } \\
\text { aspiration; right action; } \\
\text { correct livelihood, } \\
\text { rightful mindfulness and } \\
\text { concentration }\end{array}$ & $\begin{array}{l}\text { Visits to temples to pay } \\
\text { homage to Tian (God or } \\
\text { Heaven), Confucius, and } \\
\text { ancestors; practice Jing } \\
\text { zuo or "Quiet Sitting" }\end{array}$ \\
\hline
\end{tabular}




\begin{tabular}{|c|c|c|c|}
\hline Categories & Daoism & Buddhism & Confucianism \\
\hline Principles: & $\begin{array}{l}\text { The Dao is the Way; de } \\
\text { is power/virtue; wuwei } \\
\text { is "no action" or "action } \\
\text { as non-action" or- } \\
\text { better-restrained action } \\
\text { in accord with nature; qi } \\
\text { is the circulating energy } \\
\text { and vitality coursing in } \\
\text { and through the body }\end{array}$ & $\begin{array}{l}\text { Life is suffering and } \\
\text { the only way to escape } \\
\text { suffering is to dispel } \\
\text { one's cravings and } \\
\text { overcome ignorance by } \\
\text { realizing the Four Noble } \\
\text { Truths and practicing the } \\
\text { Eightfold Path }\end{array}$ & $\begin{array}{l}\underline{\operatorname{Rén}} \text { (benevolence, } \\
\text { humaneness); } \underline{Y i} \\
\text { (righteousness or } \\
\text { justice); } \underline{L i} \text { (proper rite); } \\
\text { Zhì (knowledge); Xìn } \\
\text { (integrity) }\end{array}$ \\
\hline $\begin{array}{l}\text { Attitudes toward } \\
\text { Nature: }\end{array}$ & $\begin{array}{l}\text { A Daoist ontology } \\
\text { where the body, } \\
\text { earth, and cosmos (or } \\
\text { the heavens) are not } \\
\text { radically separated } \\
\text { from one another, but } \\
\text { mutually interpenetrate } \\
\text { and pervade each other; } \\
\text { the liquid ecology, } \\
\text { porous body, and } \\
\text { re-enchanted cosmos are } \\
\text { rewoven into a holistic } \\
\text { dialogically transcendent } \\
\text { framework through } \\
\text { Dao as the Way and the } \\
\text { qi (energy) coursing } \\
\text { through channels } \\
\text { connecting the body } \\
\text { with nature, landscapes, } \\
\text { the universe, and the } \\
\text { constellations }\end{array}$ & $\begin{array}{l}\text { Changeability is one of } \\
\text { the perennial principles } \\
\text { of nature. Everything } \\
\text { changes in nature } \\
\text { and nothing remains } \\
\text { static; nature passes } \\
\text { through alternating } \\
\text { cycles of evolution and } \\
\text { dissolution; because } \\
\text { Buddhism tirelessly } \\
\text { advocates against the } \\
\text { vices of greed, hatred, } \\
\text { and delusion in all } \\
\text { human pursuits, it calls } \\
\text { for humans to live } \\
\text { a simple life with few } \\
\text { wants }\end{array}$ & $\begin{array}{l}\text { While Confucius } \\
\text { expressed some positive } \\
\text { things about nature } \\
\text { and the environment, } \\
\text { Confucianism is } \\
\text { predominately } \\
\text { anthropocentric and thus } \\
\text { human relationships and } \\
\text { concerns remain at the } \\
\text { center of its teachings }\end{array}$ \\
\hline
\end{tabular}




\begin{tabular}{|c|c|c|c|}
\hline Categories & Daoism & Buddhism & Confucianism \\
\hline $\begin{array}{l}\text { Views toward other } \\
\text { religions: }\end{array}$ & $\begin{array}{l}\text { Not tied to absolutes } \\
\text { or single faiths of } \\
\text { Abrahamic religions }\end{array}$ & $\begin{array}{l}\text { As a religion and } \\
\text { practical philosophy, } \\
\text { Buddhism remains } \\
\text { neutral and open to other } \\
\text { religions }\end{array}$ & $\begin{array}{l}\text { No contradiction in } \\
\text { following other religions }\end{array}$ \\
\hline $\begin{array}{l}\text { Views toward other } \\
\text { Dharmic religions: }\end{array}$ & $\begin{array}{l}\text { Daoism has been } \\
\text { influenced by Buddhism } \\
\text { and resonates with } \\
\text { some commonly shared } \\
\text { ideas and values while } \\
\text { it is more distant } \\
\text { from Confucianism } \\
\text { despite some residual } \\
\text { similarities }\end{array}$ & $\begin{array}{l}\text { Many teachings and } \\
\text { ideas of Buddhism } \\
\text { and Daoism overlap, } \\
\text { while Buddhism and } \\
\text { Confucianism have } \\
\text { been more oppositional } \\
\text { toward one another }\end{array}$ & $\begin{array}{l}\text { Confucianism and } \\
\text { Daoism share certain } \\
\text { superficial similarities } \\
\text { and Confucianism } \\
\text { has been historically } \\
\text { antagonistic toward } \\
\text { Buddhism }\end{array}$ \\
\hline
\end{tabular}

reason/faith, local/global) still inhabiting Enlightenment thinking. Such an Enlightenment influence shapes our perceptions, orientations, and programs for living, and directs personal actions and public policies like sustainable cities in the East and West. Part of the task Miller sets himself in this book is to clarify how Daoism, as it has evolved from its early philosophical beginnings, articulates nature and religion differently from modern Western ways of thinking about these concepts and how these categories have relevance for rethinking humans in the world and the world in humans. For Daoism, the body, earth, and the cosmos or the heavens are not radically separated from one another. Indeed, these three domains mutually interpenetrate and "pervade" each other so that the liquid ecology, porous body, and re-enchanted cosmos are rewoven into a holistic dialogically transcendent framework. Through Dao as the Way and through the $q i$ (energy) coursing through channels connecting the body with nature, landscapes, the universe, and the constellations, we are led to an "inner alchemy" taking the expression of body cultivation practices paralleling an "outer alchemy" where through the refinement of minerals and other natural substances Daoists work to produce an elixir of immortality (Miller 2017: 62).

Even more, the human body and body of nature and landscapes, far from being disenchanted as in the modern worldview, are analogically linked by a transformative power that points to the inner connections of both bodies through their respective organs (the human heart, kidneys, etc. with nature's sacred mountains, grotto chambers, and caves) in a spatial sense that breeds an emphasis on the primacy of the local and a locative imagination. Faithful to its holism, this spatiality in the body and earth in Daoism, according to Miller, extends to the cosmos through the concept of $w u$ as "non-being" or "emptiness" that characterize the heavens as well as the earth, and the body. In Daoist 
cosmology, then, the dimensions of body, mountain, and sky are understood as locations in which things take place, most notably the encounter with perfected beings who "'take up residence' in the sky, mountain, and body" and thus are spaces for inhabitation (Miller 2017: 96).

These and other Daoist themes and tropes produce, not merely a trenchant critique of developmentalism, instrumentalism, and the Enlightenment's shadow (the impulse to dominate), but a decisive shift from environmentalism to ecological holism - especially in regard to nature. Whether attacking mainstream environmentalism's perception of nature or environment as that which is out there and separated from urban life or key aspects of Western humanism, Miller shows how Daoism goes beyond environmentalism, preservationist, and conservationist notions of nature: it takes the form of national parks, virgin forests, wetland conservation and preservation, rejecting instrumentalist and rational bureaucratic orientations and restoring ontological linkages underpinning body, earth, and the heavens.

So subtle and radically penetrating is his critique of enlightened modernist thought that he makes the seemingly outrageous claim that China does not have an environmental problem requiring solution through Western techniques and their supportive cultural-intellectual (Enlightenment) paradigm and religious (monotheistic Christian, largely Protestant) moorings. Rather, its supersession is to be found in the recovery of the eco-knowledge and wisdom of an ever-unfolding Daoist holism and its re-functioning toward the future (see Box I.1).

\section{BOX I.1 PARALLELS IN DAOISM AND ECOLOGY}

1. The outlooks of the Daodejing and Zhuangzi differ in a meaningful way from Western ideas about the problematic binary humanity/nature. In the Daoist understanding, nature is not something outside of us, but rather a mental attitude, as well as the true condition of one's body.

2. The body is seen as a microcosm, containing all dimensions of reality, including what is in Western terms regarded as nature. The body is thus porous, and not characterized by clear limits to the outside world, an attitude that can be illustrated by the act of breathing.

3. A radical perspective on our temporal situation. In the classic texts of Daoism, the modern Western notion of linear time is not to be found. Time is largely regarded as cyclical, which unsettles such ideas as the Western myth of progress.

4. The emphasis on local ecology. Daodejing and Zhuangzi repeatedly draw attention to the intrinsic qualities in things and living beings in the 
immediate environment. The profound respect for all manifestations of life is the basis of the moral advice given in both texts.

5. Cosmic ecology. The Daoist universe is characterized perhaps most famously by the dynamic pattern of yin and yang, which stand for the contraction and expansion, respectively, of a kind of cosmic heartbeat. The universe is thus seen as an organism, spontaneously regenerating and renewing itself.

Source: Summarized from Brunskow (2017: 9).

Asking why Sinologists often fail when they try to define what Daoism is, Miller notes how even close students of Chinese religion, including Daoist thought, tend to read Daoism through Western cultural categories derived from their understandings of "religion" as it emerged in Occidental culture. Thus, even the most noted scholars of Chinese religion like Joseph Needham fail to excavate and put in doubt the assumptions and supposedly universally applicable character of these culturally hide-bound, parochial notions underpinning the questions raised and phenomena they seek to analyze. The preponderant literature from this tradition then wastes time and intellectual energy trying to determine whether Daoism is a philosophy or a religion and often contents itself with dividing Daoism into two (or more) phases where it supposedly had the features of a philosophy originally and then later on took on the trappings of a kind of religion (Miller 2017: 133-135). As a result, much of Western scholarship "essentializes" supposed markers of religion based upon the Western experience.

While nowhere cited in this book, Miller is familiar with Ernst Bloch's philosophy of hope, as revealed in some of his other writings, and the overriding thrust in his concluding chapters, and is clearly tacitly inspired by Blochian themes like the modality of hope and the virtues of non-contemporaneous contradictions and the notion of critical inheritance. Here, Miller treats Daoism neither as a "philosophy" nor as a "religion" in Western senses, but a body of holistic thought and practice that dovetails with lived in sustainability and an ecological worldview and operates as an alternative modernity.

How then can Daoism and the blended popular religions practiced by urban and rural inhabitants alike in their quotidian lives come to promote sustainability and serve as the basis for an alternative modernity? Ernst Bloch's three-volume work The Principle of Hope (1986) lights the way. There, Bloch recognized that pre-modern and even anti-modern elements of earlier times act as non-contemporaneous contradictions in present-day politics often expressed in conservative and even reactionary articulations. Their task, he observed, was to shoulder the responsibilities of active inheritance as a form of hegemonic articulation of the cultural surplus of these ideas. For Bloch, their 
political-cultural potential as elements of a forward coalition of forces promoting fundamental change is to "pay the debts of the past in order to receive the present" (Howard 1977b: 66-67) by re-articulating and re-functioning every value and ideal expressed in the existing remnants of past and evolving articulations and can only be truly realized from this cultural surplus in society, culture, and economy in a future yet to be made (Bloch 1977).

As Miller-joining Smith - shows, Daoism and strong sustainability do not present religion as a problem to be solved (Miller 2017: 142; Smith 1982). That is, it "does not 'produce' religion in the same way that modernity, as a cultural paradigm, does. Rather, the paradigm of sustainability asks what worldviews, values, and social networks can produce a continuity of the human species together with the ecological systems of the planetary biosphere" (Miller 2017: 142). Moreover, Daoism as eco-theory embedded in a holistic and interpenetrating vision of body, earth, and heaven(s) derived from its cultural surplus in the past can be reconstructed and re-functioned as a source and force for assisting other pre-modern, anti-modern, and postmodern groups to re-theorize and re-enact a way toward a sustainable future for China. And through this re-theorization and re-enactment, he argues, an "alternative, practical reading of human engagement with nature [derived from the Daoist imagination] can emerge from this, one that need not be limited to Daoism or Chinese approaches to sustainability but one that can inform the environmental humanities more broadly" (Miller 2017: 146).

Finally, venturing forth from the aesthetics and ethics of flourishing, Miller grapples with its politics. There, he argues that the cultivating of human flourishing requires a transfigured politics - one that while embracing the Chinese party-state's call for an ecological civilization, declares forcefully that it must overcome its contradictions with the kind of eco-modernization strategy founded in Enlightenment modernity and cannot be attained "at the expense of rural spaces, marginalized people, or through prejudice against ethnic minorities. Such a politics will also follow Daoism too in its focus on the local - including local governance, and local political issues" (Miller 2017: 162). In keeping with the importance attached to balance in Daoist thought, Miller points to China's need to rethink its frenetic race toward urbanization and reorder its priorities between urban and rural habitat. Here, he hints at, but does not fully articulate, the need for sustainable city-regions, a new ecological relationship between city and countryside, and the need to rehabilitate and lay groundwork for democratic politics to forestall hopeful ecological developments from surrendering to the bureaucratic pathos of the Chinese state (Miller 2017: 163). 


\section{CHAPTER SUMMARIES}

Chapter 1 of this book, "Theoretical foundations of the sustainable city-region," lays the groundwork for our examination and critique of the Chinese eco-urbanization strategy by offering an alternative way of conceptualizing sustainable or eco-cities developed by the co-authors over thirty years. Working from a strong sustainability position elaborated in the chapter, we outline the theory of sustainable city-regions by highlighting its key components. Benefiting from pioneering work of William Rees and Mathis Wackernagel, we develop as the first component our own variation on their idea of a fair Earthshare - the Sustainable Area Budget (SAB) - which, we argue, provides the basis for promoting sustainability as process, not as pathway. This reconceptualization allows us and others following Rees and Wackernagel's "ecological footprint" analysis to use the fair Earthshare or $\mathrm{SAB}$ as a reasonably precise sustainability metric or system boundary within which sustainable regimes may be explored in both qualitative and quantitative formulations.

We then introduce the Sustainable City Game by showing how the Sustainable Area Budget paves the way for literally playing a game and for scaling up and revising the game so that it can become a policy process for producing multiple scenarios generated by key stakeholders using advanced computer software, not to solve nagging urban policy problems, but rather for generating cities where the problems, that have been plaguing them do not even appear.

The Sustainability Engine ${ }^{\mathrm{TM}}$ is the third element of our strategy of sustainable city-regions. The Engine may be interpreted as the AI (artificial intelligence) that is both a form generating utility and a feedback tool within the Sustainable City(-Region) Game. Storing the various data (energy, material flows, 3D visualization models, etc.) in its memory, the Sustainability Engine ${ }^{\mathrm{TM}}$ houses the multiple scenario-building process where proposed alternatives are negotiated, modeled, and stored, providing feedback to stakeholders as to the character and quality of their competing urban scenarios and the state of their metabolic balances within the boundaries of their Sustainable Area Budget. As we demonstrate, the mutual relationship between the Sustainable Urban Implantation and its Rural Partnerland are clarified.

We emphasize here that the hybrid character of the city-region is the proper scale of our theory or approach. As such, it couples the two to achieve an integrated urban-rural platform for giving material form to the Sustainable Area Budget by satisfying the requirements, needs, and desires of the inhabitants of the sustainable city-region, individually and collectively through a structured negotiation process. Along the way, details are given and examples provided 
for each of the key features. The chapter concludes by delineating important lessons for sustainable city-building.

This initial chapter closes with an appreciative critique of the Rees and Wackernagel Ecological Footprint Analysis. Its intent is both to differentiate their valuable approach from our somewhat overlapping strategy of sustainable city-regions and to rehabilitate the crucial importance of the notion of carrying capacity for sustainable development and urban sustainability studies now all but forgotten as a means to ground strong sustainability theory and practice.

Chapter 2, titled, "Eco-city development strategy in Beijing and China's cities: top-down/bottom-up dynamics," begins with discussing the origins and history of China's pursuit of an ecological civilization. It then examines the general thrust of China's eco-city development strategies for advancing its overall goal of converting its foundations into an "ecological civilization." In its striving to establish a new and modern urbanization process and a new ecological type of city-building, the Chinese party-state has sought to promote a multitude of eco-urbanization variants at different scales (towns, cities, districts, counties, and provinces) and urban types (eco-city, low-carbon city, low-carbon eco-city, smart-city, and eco-knowledge and knowledge cities) that are driven by a marriage of top-down and bottom-up dynamics.

Looking first at the top-down forces propelling Chinese eco-cities, we illuminate the central role played by two national ministries, the Ministry of Environmental Protection and Ministry of Housing and Urban-Rural Development, and one higher state organ, the National Development and Reform Commission. These national organs are responsible for picking towns and cities, as well as counties, districts, and provinces, as eco-urbanization sites, then monitoring their implementation and progress, and even awarding them for superior performance in their particular categories. As a fragmented authoritarian state, the party-state also leaves to lower scaled governmental entities formal and informal mechanisms and patterns to inform and drive urban processes shaping eco-urbanization politics. These too are sketched in broad brush strokes in the second chapter, leaving more detailed analyses to populate succeeding chapters. From there, we investigate the guiding frameworks and favored metrics used by MEP, MoHURD, and NDRC, often delegated to lower-scale governance agencies for implementation. Because eco-indicators have been the overwhelmingly favored policy instruments for assessing eco-urbanization performance and progress, we turn to an enumeration of these sustainability indicators used by these central governmental organizations and then provide a critique of indicator systems juxtaposed against our preferred strong sustainability metric - the Sustainability Area Budget - and in terms of the weakness of indicators as eco-measures in the ways in which they are grounded in the notion of sustainability as pathway. 
Chapter 3 discusses the process of emergence and dispersion of eco-city and low-carbon city initiatives across the People's Republic of China. Titled, "Suzhou, Wuxi, and China's twenty-first century eco-city program: from austerity ecology to eco-scientific plenty," the chapter offers case studies of two of the five eco-city developments studied in recent fieldwork: the Suzhou New District and Eco-Town and the Wuxi New District and Taihu Eco-city.

First, the backstories of each are sketched to demonstrate their crucial importance. In the case of Suzhou, the narrative highlights the way the evolution of Suzhou New District (SND) came to be locked in a fierce conflict with the Sino-Singapore Suzhou Industrial Project (SIP). The reasons why the locally driven eco-development (the SND) ultimately defeated the Sino-foreign project (SIP) is a fascinating story that explains much about the power and limits of such hybrid eco-developments. The case also points to the advantages that locally-generated and -promoted land projects can muster even when pitted against an influential Chinese partner like Singapore and arrayed against Beijing party-state leaders and administrators.

In respect to the Wuxi case, we explore the importance of its history for understanding its prominence, first, as an agricultural center, then as a textile industry and then light and heavy manufacturing center in Jiangsu province. Drawing upon recent urban historiography, we trace its burgeoning as an economic powerhouse well before the Opening and Reform era inaugurated by Deng Xiaoping. Our reprise on its economic prominence prior to 1979 also underlines the point that economic growth in the city proper and those rural villages forming the region occurred essentially as a single process led by wealthy urban families and then fostered by local and state authorities during the Second Sino-Japanese War.

The other facet of its backstory involves Wuxi's venture into eco-city building as a Sino-Swedish eco-city project. Its peculiarities say much about the vicissitudes of native-foreign hybrid eco-city projects (Dongtan, Caofeidian, etc.) that merit analysis and comparison with other such Sino-foreign eco-projects never completed stemming from the obstacles that emerged and the individual partner expectations that were dashed during the implementation of the mutually agreed upon plans. While we do not enter into an accounting of larger patterns of failure of such eco-hybrid ventures, we enumerate upon the lessons drawn by a former MoHURD official from such failure or moribund eco-partnerships.

This chapter then dwells on the valuable insights culled from the Suzhou original and then SND urban planning exhibition halls and the Wuxi exhibition museum for uncovering key components fueling the Chinese eco-urban development strategy. To better understand the significance of these components, we critically appropriate from the small but insightful literature on the origin of the modern museum and its special place in Communist eco-urban 
projects dotting the Chinese landscape. Using historical and comparative research of the many urban planning exhibition museums in these cities and in some cases inspired by the writings of Michel Foucault, these studies bring to light a utopian dream of future happiness residing deeply buried in Maoist Communist ideology. This prompts us to see in these exhibition halls that post-Maoist utopian future built upon the "four modernizations," characterized by a "harmonious society," a "new socialist countryside," and every species of the "eco-city" of the future. This future, we argue, is informed by six discrete ideological and political functions of the exhibition hall. It is also deeply ensconced in a set of core values founded upon the idea of eco-scientific plenty. The chapter closes with evidence of these six roles and set of values adduced by tying observations and examples from the Suzhou and Wuxi cases.

Chapter 4 is titled, "New Kunming/Chenggong eco-district: city surrounding the countryside?" Although its specific focus is the Chenggong Eco-district, it can only be properly investigated by tying it closely to the recent political and economic history and development of Kunming. Like other Chinese cities seeking to build upon legacy projects such as mega-sports and other city sponsorships, the origins of the Chenggong Eco-district project lay in the hosting of the 1999 World Horticulture Exposition and one of its legacies, the 2003 strategic development framework informing Kunming's urbanization designs. A second impetus was Kunming's first experience with Sino-foreign urban collaborations, the Zurich-Kunming partnership that contributed to serious rethinking by public officials and urban planners who benefited from Western knowledge and techniques for restructuring cities and their surrounding regions in a more rational and planning oriented way.

As the chapter unfolds, it places further emphasis on two other developments paving the way for expansion of the city to an undeveloped district to the southeast. The first was the commanding role of a rising party comer and past party deputy secretary of Yunnan province, Qiu He, who helped to catalyze industrial modernization and urban initiatives in Kunming and was called upon to draw up the blueprint and implement a vision of New Kunming City that included enlarging the city boundaries to incorporate Chenggong. Before his fall from power and expulsion from the Chinese Communist Party, he was credited with expropriating agricultural land populated by over 100,000 peasants on the periphery of Chenggong and demolishing nearly thirty villages in the vicinity to make way for the new district.

Our analysis then examines the migration of Western theories and instances of growth machine or growth coalition politics to China. Here we borrow from the work of several Chinese and Western scholars (Qian 2007; Wu and Whaley 2017; Zhang 2014) to identify a second shaping force of the Chenggong Eco-district and New Kunming City. Pointing to the similarities and differences in the operation of growth coalitions in North America and China, 
we utilize the informal growth coalition to identify some of the more salient features of its sway in the continued horizontal urban sprawl of Kunming to its hinterlands and ponder Chenggong Eco-district's reputation for devolving into one of China's reputed "ghost cities." In the context of underscoring these two local-regional developments, we point to at least two factors that more generally propel the bottom-up dynamics of the Chinese eco-city strategy.

In this respect, we strive to press deeper by reviewing and seeking to adjudicate at least three conflicting interpretations of land-lost peasant attitudes toward state expropriation of rural land - an oft-chosen policy tool for acquiring land for eco-urbanization projects in China. Yang Cheng's study (2014) of a sample of the experiences of land-lost peasants from three villages on the outskirts of Chenggong contrasts in important respects with the longitudinal study of the rural village of Xiaocun at the entry point of what would become Chenggong by Zhu Xiaoyang $(2014,2015)$.

We follow the summary and analysis of Yang and Zhu's more benign interpretations and conclusions with Hsing's (2010) more general overview and reading of the plight of land-lost peasants, land expropriation, and resettlement. Chen's highly critical investigation of the impact of the construction of Yixing New City upon the "green dispossession" and forceful uprooting of rural villagers in the surrounding countryside then follows. In the process, we bring to light the findings of his fieldwork to show how this "green leap forward" used its environmental rationale to strip these land-lost peasants of supposed village collective protections and, in contrast to Yang's findings, beggared their lives and livelihood in the name of building an eco-city and ecological economy.

While the manifest differences and often opposing readings of the villagers' attitudes toward local state appropriations of their property and submarket compensation packages are difficult to reconcile with one another, this chapter seeks to avoid the kind of "positional superiority" Vukovich (2012) chastises Western researchers and policy makers for. To do so we turn to Elizabeth Perry's (2008) work to find a somewhat independent foundation (without being grounded in any evidence from fieldwork in Kunming and Chenggong) to provisionally and cautiously embrace a thin basis for mediating between the two starkly contrary interpretations - one that builds upon Perry's view of Chinese citizen/subject rights as an expression of the right to subsistence and socio-economic development combined with a paternalistic view of the emperor and state that justifies the right of popular revolt as an appropriate response to the emperor's failure to rule in a manner that satisfies this responsibility stemming from the Confucian "moral economy."

Chapter 5, "Shantou: a metropolitan coastal garden-city in the making?," seeks to address the overriding question featured in its title. A southern Chinese city known for its native Chaoshan culture and its excellent South 
China cuisine, Shantou has other resources and assets that would prompt one to expect that its economic development and interest in becoming a distinctive eco-garden city would go hand in hand. Yet behind its historical advantages and accolades has materialized a story of longstanding political corruption and squandered economic opportunities. Though a city blessed with several generations of native inhabitants and entrepreneurs who joined the Chinese diaspora to gain enormous fortunes in surrounding South and East Asian nations, Shantou's municipal governance has been reputed to be a playground for public officials and staff who have often skimmed from the city treasury, perpetrated tax fraud, stolen from its road and other infrastructure budget, and driven away wealthy business people's philanthropy that might otherwise improve its social and economic opportunities, cultural institutions, and largely undeveloped urban design and public spaces. Since the new millennium, various forces in Shantou have sought to overcome its seamy political reputation and economic backslide by new policy tools (a new strategy, a new master plan, and a new vision) to restore its early nineteenth-century reputation as leader of Guangdong province's economy, put its urban house in order, and clean up its environmental degradation and deteriorating center city.

In analyzing Shantou's efforts to reinvent itself and its identity, we develop a framework for evaluating the city's policies and programs to realize these goals drawing upon assemblage theory. Utilizing the work of Ananya Roy, Aihwa Ong, Glen Lowry, and Eugene McCann (among others) that finds its inspiration from French poststructuralists Gilles Deleuze and Félix Guattari, we continue our efforts to get at the politics of sustainable city and eco-city development. We endeavor to accomplish this by contextualizing policy assemblages, mobilities, and mutations to re-found Duara's concept of circularities. At the same time, we show how the "worlding of cities" today is a process that globalization not only abets, but leads to the circulation and sharing of ideas, policies, tools, priorities, and strategies and contributes to a conceptualization of policy assemblages as a worthwhile tool for analyzing the who, wherefore, and why of policy generation and transfer as well as the emergence of a new way of looking at power.

This focal concern then motivates us to construct a policy assemblage composed of elements both operating in and through Shantou's bid for economic revival and ecological restructuring. Our analysis displays those elements both currently present (e.g. Shantou Urban and Rural Planning Bureau, Shantou Urban Planning and Design Institute, Nanjing Urban Design Institute, various international consultancies) and those notably absent (e.g. Shantou University, Li Ka-Shing Foundation, MoHURD) from the outlined assemblage. Its purpose is intended to suggest why its objective to become a metropolitan coastal garden-city is likely to fail if currently missing components are not integrated into the policy assemblage. 
The remainder of the chapter applies the Shantou policy assemblage to illuminate the evolution and substance of two documents: the Shantou Strategic Plan and the Shantou Master Plan. In so doing, it attempts to fulfill the promise of assemblage theory for understanding the local-regional-national-global dynamics bearing upon the policies and goals of this South China city. The chapter concludes by completing three tasks. First, it demonstrates why Shantou was selected and how it fits into an eco-city type excluded from de Jong et al.'s four-typology model. Second, it explains why more cooperative policies and programs did not appear in the Chaoshan region comprising Shantou, Jieyang, and Chaozhou that might have involved these two nearby cities to develop regional responses to economic decline. Finally, the chapter offers a prognosis on the likelihood of Shantou becoming a metropolitan, coastal garden-city and indicates the value of assemblage theory for diagnosing its prevailing circumstances and driving forces and for evaluating its prospects for success.

"Beyond the Dongtan debacle: Tianjin and global showcase urban sustainability" is the title of Chapter 6. Recognizing that the Sino-British Dongtan-Chongming Island eco-initiative has been moribund for ten years and no longer figures as a Sino-foreign showcase eco-city, we engage in a reprise of the high hopes vested in it by the People's Republic of China, the city of Shanghai, and Arup, Britain's preeminent engineering consulting firm, by juxtaposing two often conflicting interpretations by I-Chun Catherine Chang (2015, 2017a, 2017b) and Julie Sze (2015) of Dongtan's intended goals and potential as a serious eco-city and shining Chinese eco-polis to the world. While it would ultimately prove to be a failure and become mired in scandal, we show how it has lived on in new planning tools fashioned by Arup, influenced the design and construction of eco-urban copycats across China and the globe, and shaped some of the features of the Sino-Singapore Tianjin Eco-city (SSTEC), the major subject of this chapter.

As we turn to the SSTEC in order to delineate its transition to front-ranking status among Chinese eco-urbanization projects, we acknowledge the heavy investment of both Chinese and Singapore partners in seeing this eco-city initiative to completion and success, given China's desire to offer up a new model and international showcase to replace Dongtan and aid Singapore in overcoming the less than picture-book experience with its previous partnership on Suzhou's eco-urban initiative. We also applaud the Chinese planning choice of a grayfield site (i.e. a rather economically unattractive and environmentally contaminated stretch of land), rather than a greenfield area, to locate this highly ambitious eco-project. Yet, as we demonstrate, it carries with its implementation a number of shortcomings. First, as we show, it is dependent upon eco-indicators taking the form of key performance indicators (KPIs) and thus never really presents a meaningful representation of strong sustainability. 
Second, its urban architectural design and targeting to appeal to predominantly upper middle class and wealthier clientele undermines the social equity leg of the sustainability tripod. Third, its avowed commitment to public transport (walking, electric buses and taxis, light transit) conflicts with a physical design that defers to the automobile by the construction of its wide streets and roads into, through, and around the 10 kilometer eco-city. Together, these elements vitiate the promise of SSTEC and, in our professional opinion, seem to have fated the Sino-Singapore eco-experiment to become an example of the "failure of success."

The last part of the chapter contributes to the literature on sustainable urban transitions by imagining in a speculative, but-one hopes - not fanciful, manner how the re-inauguration of China and Singapore's Tianjin eco-urban venture might evolve into a strong sustainability version of an eco-city guided by this book's alternative sustainable city-region model's Sustainable Urban Implantation. This future scenario draws upon counter-hegemonic forces and factors existing or mobilizable within the contradictory real-world conditions operating in China today and the redesign of the Tianjin Eco-city's center city and urban planning exhibition hall into an adumbration of a Sustainable Urban Implantation on the model of a City-as-a-Hill.

The final chapter 7 seeks to recapitulate some of the major themes of the book and to offer a series of policy recommendations flowing from the critical analyses in the individual chapters and case studies. In juxtaposing the Chinese eco-urbanization strategy against the three-decade-long strategy of sustainable city-regions advanced by the co-authors, we acknowledge that this book is not for the philosophically faint of heart or for those who are satisfied with easy formulas, attractive techno-fixes, simple measuring rods, or linear pathways to local-global sustainability. It demands instead a willingness to suspend allegiance to these shortcuts to substitute hard thinking, a readiness to cultivate a subtle appreciation of comparative historical analysis, and most of all openness to experimentation beyond the conventional, routine, and even best practices toward the policy issue of our times. For this reason, looking for real-world examples of possible models of strong sustainability solutions we close with brief analyses of the Beddington Zero Energy Development (BedZED) project in London and other openings toward building sustainable cities and eco-communities upon eco-footprint foundations. These examples offer encouragement that a sustainable city-region approach could establish roots in China and perhaps serve as a beacon of hope and possibility for other nations to emulate in their teeming cities slouching toward eco-catastrophes in a hot and crowded, increasingly right-wing populist, and violent world. We close with a long meditation on the convergence of China's massive urbanization process and its quest to build an ecological civilization that would constitute that next step from eco-cities to sustainable city-regions. 
The appendix, "The Sustainable City-as-a-Hill as sustainable city-region," elaborates on the Sustainable Urban Implantation qua City-as-a-Hill. It presents a partly visual overview of the historical development of the city-on-a-hill in medieval hilltowns in Italy like Asissi and exhibits how sustainability and its challenges became the motivation for evolving of necessity a new structure of urbanism based upon old models of proto-sustainability from the past. Several architectural design projects responding to policy demands in Vienna, Austria, Whitesberg, Kentucky, and Milwaukee, Wisconsin are presented to manifest the ingenuity and flexibility of the City-as-a-Hill model in different geographical contexts. 
Ernest J. Yanarella and Richard S. Levine - 9781839102783 Downloaded from PubFactory at 04/26/2023 01:13:17AM via free access 